\title{
Acetic acid bacteria: features and impact in bio-applications
}

\author{
Isidoro Garcia Garcia, ${ }^{1}$ Maria Gullo² \\ ${ }^{1}$ Chemical Engineering Department, University of Córdoba, Spain; ${ }^{2}$ Department of Life Sciences,
University of Modena and Reggio Emilia, Italy
}

\begin{abstract}
Acetic acid bacteria are a group of microorganisms able to achieve oxidation reactions from sugars and alcohols mainly producing organic acids, aldehydes and ketones. When the substrate is ethanol, acetic acid is produced, thus giving the common name acetic acid bacteria to this bacterial group. Acetic acid bacteria are of considerable importance in food and beverages as beneficial or detrimental bacteria. Nowadays, they play a role as biocatalysts contributing to more eco-friendly bio-based processes, since the production of important industrial molecules generate high environmental impact when chemically synthesized. Although they have a high biotechnological potential, their use at industrial scale is still restricted.

The Third International Conference on Acetic Acid Bacteria - Vinegar and Other products, held in Cordoba (Spain), in April 17-20, 2012 (http:/www.uco.es/aab2012/) highlighted several aspects related to acetic acid bacteria in foods, beverages and industrial chemicals production as well as their potential for many new applications.

This Special Issue reports a selection of papers from this last Conference dealing with the enzymatic machinery of acetic acid bacteria, ecological and physiological features as well as new advances in their application. First, a comparative study is provided about molecular and catalytic properties of the active and inactive forms of alcohol dehydrogenase (ADH) enzyme from the $\mathrm{N}_{2}$ fixing Gluconacetobacter diazotrophicus. ${ }^{1}$ The ability to oxidize ethanol and to tolerate increasing acetic acid concentrations are basic requirements for the survival of acetic acid bacteria when applied as microbial cell factories in vinegar production. A paper dealing with the functional analysis of the acetic acid resistance gene cluster of industrial Acetobacter strains is also included. ${ }^{2}$ Although grape must and wine are well studied niches of acetic acid bacteria, two papers highlight the detection of a larger species diversity respect that traditionally described, when robust molecular tools are applied. ${ }^{3,4}$ The production of vinegar in Asiatic countries strongly differs in raw material and applied technology respect to the Western production. Here, a study on the composition of the Shanxi Aged Vinegar obtained from cereals fermentation is reported. ${ }^{5}$ Microbial cellulose is becoming a high-demand polymer in different fields.
\end{abstract}

Correspondence: Isidoro Garcia Garcia, Chemical Engineering Department, University of Córdoba, P.0. Box 14071, Córdoba, Spain.

E-mail: iqlgagai@uco.es

Key words: acetic acid bacteria, bio-applications, international conference.

Received for publication: 8 February 2012.

Accepted for publication: 8 February 2012.

This work is licensed under a Creative Commons Attribution 3.0 License (by-nc 3.0).

(C) Copyright I. Garcia Garcia and M. Gullo, 2013

Licensee PAGEPress, Italy

Acetic Acid Bacteria 2013; 2(s1):e1

doi:10.4081/aab.2013.s1.e1
Gluconacetobacter xylinus is a plant-associated bacterium considered a model organism for studying cellulose synthesis. A paper reviews the effect of plant phytohormones on the growth and structural features of cellulose, showing that these plant regulators stimulate $G$. xylinus growth and influence its pellicle characteristics. ${ }^{6}$ Among new bioprocesses aimed to sustainable productions, the stabilization of cheese whey, an important source of environmental pollution, is also covered through the development of a stable nutrient recycling system as an ingredient in dairy cattle diet. ${ }^{7}$ Last but not least, the maintenance of authentical strains over the preservation time is a priority for the exploitation of acetic acid bacteria as a microbial cell factory. One review focuses aspects related to the effect of long-term preservation of strains in culture collections. ${ }^{8}$ Also the consequence of preservation techniques on cell viability is provided by a paper on the evaluation of cell survival to freeze-drying processes. ${ }^{9}$

Finally, we hope that in the frame of a multidisciplinary approach intended to support basic and applied research on acetic acid bacteria, this issue will contributes to strengthen the activity of the Acetic Acid Bacteria Research Network (http//www.uco.es/aab/) as platform for the enhancement of acetic acid bacteria research.

\section{References}

1. Gomez-Manzo S, Del Arenal-Mena IP, Escamilla E. The inactive and active forms of the pyrroloquinoline quinone-alcohol dehydrogenase of Gluconacetobacter diazotrophicus: a comparative study. Acetic Acid Bacteria 2013;2(s1):e2.

2. Mullins EA, Kappock TJ. Functional analysis of the acetic acid resistance (aar) gene cluster in Acetobacter aceti strain 1023. Acetic Acid Bacteria 2013;2(s1):e3.

3. Navarro D, Mateo E, Torija $\mathrm{M}^{\mathrm{a}} \mathrm{J}$, Mas A. Acetic acid bacteria in grape must. Acetic Acid Bacteria 2013;2(s1):e4.

4. Sagarzazu NI, Martínez M, Algarra C, et al. Optimization of denaturing high performance liquid chromatography technique for rapid detection and identification of acetic acid bacteria of interest in vinegar production. Acetic Acid Bacteria 2013;2(s1):e5.

5. Chen T, Gui Q, Shi JJ, et al. Analysis of variation of main components during aging process of Shanxi Aged Vinegar. Acetic Acid Bacteria 2013;2(s1):e6.

6. Qureshi 0, Sohail H, Latos AJ, Strap JL. The effect of phytohormones on the growth, cellulose production and pellicle properties of Gluconacetobacter xylinus ATCC 53582. Acetic Acid Bacteria 2013;2 (s1):e7.

7. Lustrato G, Salimei E, Alfano G, et al. Cheese whey recycling in traditional dairy food chain: effects of vinegar from whey in dairy cow nutrition. Acetic Acid Bacteria 2013;2(s1):e8.

8. De Vero L, Giudici P. Significance and management of acetic acid bacteria culture collections. Acetic Acid Bacteria 2013;2(s1):e9.

9. Shafiei R, Delvigne F, Thonart P. Flow-cytometric assessment of damages to Acetobacter senegalensis during freeze-drying process and storage. Acetic Acid Bacteria 2013;2(s1):e10 